1 Department of Global Health and Development, London School of Hygiene and Tropical Medicine, UK

2 Institute of Health Policy, Management and Evaluation, University of Toronto, Canada

3 Johns Hopkins Bloomberg School of Public Health, USA

4 Dalla Lana School of Public Health, University of Toronto, Canada

5 Saw Swee Hock School of Public Health, Singapore

6 The Independent Panel for Pandemic Preparedness and Response Secretariat

7 School of Public Health, Boston University, USA

8 Faculty of Medical and Health Sciences, University of Auckland, New Zealand

Correspondence to: $\mathrm{H}$ Legido-Quigley ephhlq@nus.edu.sg

Cite this as: BMJ 2021;375:e068954 http://dx.doi.org/10.1136/bmi-2021-068954 Published: 29 November 2021

COVID-19 PREPAREDNESS AND RESPONSE: IMPLICATIONS FOR FUTURE PANDEMICS

\title{
National responses to covid-19: drivers, complexities, and uncertainties in the first year of the pandemic
}

Anne-Sophie Jung and colleagues argue that research and policy making must embrace complexity to build sustainable and long term approaches to pandemic preparedness

Anne-Sophie Jung, ${ }^{1}$ Victoria Haldane, ${ }^{2}$ Rachel Neill, ${ }^{3}$ Shishi Wu, ${ }^{4}$ Margaret Jamieson, ${ }^{2}$ Monica Verma, ${ }^{5}$ Melisa Tan, ${ }^{5}$ Chuan De Foo, ${ }^{5}$ Salma M Abdalla, ${ }^{6,7}$ Pami Shrestha, ${ }^{5}$ Alvin Qijia Chua, ${ }^{5}$ Nellie Bristol, 6 Sudhvir Singh, ${ }^{6,8}$ Michael Bartos, ${ }^{6}$ Shunsuke Mabuchi, ${ }^{6}$ Mathias Bonk, ${ }^{6}$ Christine McNab, ${ }^{6}$ George K Werner, ${ }^{6}$ Raj Panjabi, ${ }^{6}$ Anders Nordström, ${ }^{6}$ Helena Legido-Quigley ${ }^{1}, 5,6$

The scale and duration of the pandemic has challenged national and global abilities to develop, implement, and sustain responses that save lives and livelihoods. Responses to the pandemic have been challenged by complexity. From the evolution of the virus to the health, social, and economic effects of public health and social measures, to the forces of longstanding inequities, there is much to learn about which responses work, for whom, and why.

While it is well established that research and decision making must evaluate health systems and public health measures, often relying on indicators of health or health system capacity, this paper argues that evaluators and decision makers should consider the broader multidimensionality of health and work to establish a complete evaluation framework. Drawing on implementation research, we highlight five categories of pandemic preparedness and response that are often analysed separately or in relation to one or two other components. An analysis of responses by 28 countries to covid-19 between March 2020 and February 2021 highlighted the importance of extensive discussion. ${ }^{2}$ From this analysis, we present here a "roadmap" by which to form a concept of pandemic responses and better prepare a response to future public health emergencies. ${ }^{3-7}$

\section{Conceptualising complex responses}

As a first step towards thinking about complex responses, we present a framework to visualise categories that represent the drivers, complexities, and uncertainties inherent in responses to a pandemic (fig 1). We identify governance, control strategies, and interventions as the three pillars of a response. An "inner context" analysis discloses the importance of forming an idea of the pandemic driven and rapidly evolving conditions by which responses are shaped. In successful national responses, guided by scientific evidence, the epidemiological profile of the disease informs strategies, approaches, and interventions. As variants of concern appear, we see how the dynamic nature of the virus requires adaptable complex responses. Globally such responses have been hindered by existing structural inequities that affect health and wellbeing. These inequities are the result of longstanding ecological breakdown, systemic oppression, racism, ageism, social and economic exclusion, and other forms of discrimination. Dealing with health emergencies is intrinsically political as it depends on how government and decision makers deal with and mitigate systematic and structural elements and the uncertainties these produce, and also how they take into account more static components (eg, geography, demographics, urbanisation). Taken together, these components can strengthen our blueprint towards a more holistic understanding of what worked, for whom, and why. 
Outer context

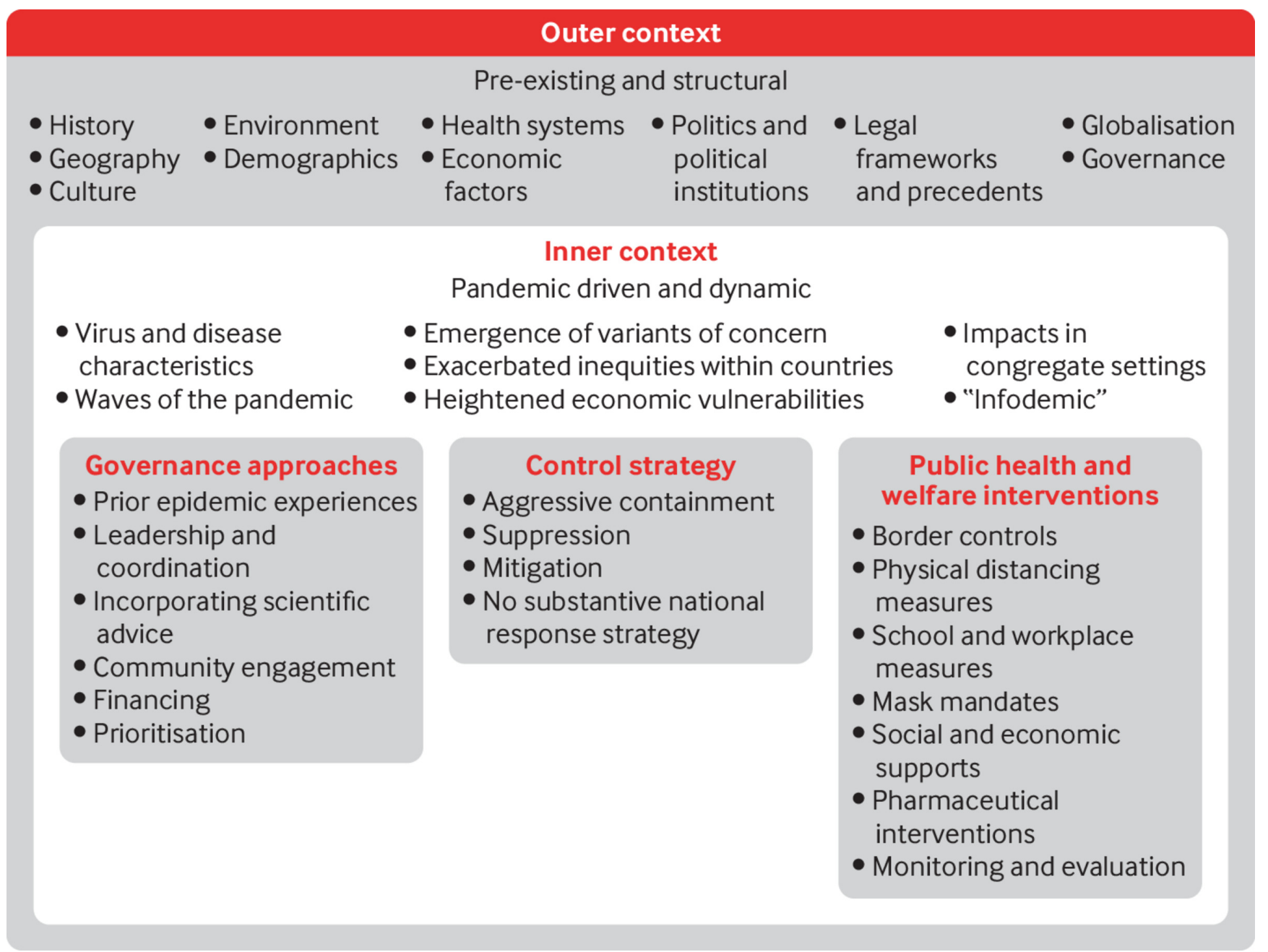

Fig 1 | Evaluation framework for responses to a national pandemic

\section{Governance approaches}

Domestic governance approaches comprise many components, including leadership, coordination, financing, and community engagement, which ideally are built on scientific advice and previous experience. Leadership and coordination ensure that scientific advice is taken into consideration and that decisions informed by science are implemented at scale. Authorities must adopt whole-of-government approaches, working closely with subnational authorities to bring together different domains and sectors. Several governments had pre-existing structures to enable this cooperation, whereas others had to create these links. Governance structures and decisions affect the financing of responses and health systems, the extent of community engagement, and socioeconomic interventions. Analysis of country responses centres on domestic governance, but international or global governance is equally critical. Similarly, using regional structures has improved collaboration for health. The procurement strategies of the African Union through the Africa Centers for Disease Control and Prevention ensured affordable prices for medical supplies. ${ }^{89}$

Financing approaches are foundational to planning a national response to covid-19 and putting it into operation. Many countries allocated additional funds to subnational governments, health ministries, or hospitals to support the overall response (see supplementary table 1 ; bmj.com). Other countries focused on direct procurement of high cost medical equipment, personal protective equipment, and medication. Countries also reallocated funds from other sectors or borrowed from international financing organisations, such as the Asian Development Bank, to rapidly procure medical equipment and medication. Funds were also channelled to the private healthcare sector through contracting essential pandemic related services, such as testing and hospital level treatment.

Community engagement is important for ensuring that interventions are feasible and acceptable to all, including equity seeking groups. ${ }^{1011}$ Community and civil society involvement also increases accountability, which is fundamental to governance at all levels. Some countries formed partnerships with local leaders to plan and deliver response measures. Community engagement in many countries relied on existing relationships with community health workers. $^{12}$

Examining the experiences of countries with past epidemics, highlights the "mental model" that countries used to guide their responses to covid-19 in 2020. In particular, influenza outbreaks were a dominant schema for many governments. ${ }^{13}$ Others looked to previous epidemics, including Ebola, SARS, MERS, and cholera. Mental models allowed countries to draw on previously developed structures and scientific advisory bodies, rather than developing them anew for covid-19. Most relied on existing institutions to 
convert emerging evidence into policy recommendations. Few countries included socioeconomic perspectives on expert advisory groups. Additionally, our data suggest that the role of scientific advisory committees has decreased over time in many countries.

\section{Control strategies}

Country strategies for control of covid-19 can be categorised as aggressive containment, suppression, mitigation, and lack of substantive strategy. ${ }^{14-17}$ These strategies are used through different combinations of public health measures. ${ }^{18}$ The aggressive containment strategy, which is usually defined as maintaining zero community transmission for more than 28 days, ${ }^{14}$ was dominant in Asia-Pacific countries. Leaders in these countries took actions based on scientific advice quickly with a strong political commitment. Most have developed a national covid-19 response strategy put into operation through a clearly centralised top down governance structure. In countries where governments adopted a suppression strategy (eg, Argentina, India, or Spain), governments responded only after the first reported domestic case by employing a series of public health interventions. Although stringent, sometimes aggressive, public health interventions (eg, lockdown) were widely used in these countries, they were usually relaxed or lifted before community transmission was eliminated. A number of European countries, including Sweden and the UK, adopted a mitigation strategy at the beginning of the pandemic. ${ }^{171920}$ These countries aimed to minimise the effects of the pandemic on vulnerable populations and to avoid overwhelming health systems by permitting controlled transmission in low risk groups. ${ }^{20} \mathrm{~A}$ few countries, including Brazil and Mexico, had no clear goal or coordinated national strategic plan for response to covid-19 in 2020, resulting in uncontrolled waves of community transmission.

\section{Programmatic interventions: health, economy, and welfare}

Programmatic interventions are a core component of responses to a national pandemic. Throughout 2020, countries relied on public health and social measures to minimise community spread, while rapidly developing pharmaceutical interventions, and offering supportive economic and social programmes. ${ }^{21}$ Travel restrictions and border closures featured in all national responses to varying degrees, with most evolving from partial to complete bans. ${ }^{22}$ Public health interventions were often coupled with social and economic support. Most countries provided some form of direct financial assistance to individuals or households, through direct cash assistance, additional payments through unemployment or welfare systems, and by pausing repayments of loans. Countries that carried out comprehensive programmatic public health interventions, while responding to the social and financial needs of communities, were more successful in reducing community transmission than those that enacted piecemeal policies. ${ }^{23}$ Table 1 gives country specific examples of interventions. 


\section{Table 1 | Examples of national response interventions in countries with low, high, and middle level covid-19 death rates}

\begin{tabular}{|c|c|c|c|}
\hline Domain & $\begin{array}{l}\text { Lowest death rates (country population }>20 \\
\text { million) }\end{array}$ & $\begin{array}{l}\text { Highest death rates (country population } \\
>20 \text { million) }\end{array}$ & Middle level death rates \\
\hline \multirow[t]{2}{*}{ Border controls } & $\begin{array}{l}\text { Uganda: } \\
\text { Borders closed on } 21 \text { March 2020, except for } \\
\text { cargo transport and import of essential goods }\end{array}$ & $\begin{array}{l}\text { Spain: } \\
\text { Land borders (later extended to include airports } \\
\text { and ports of call) closed except for returning } \\
\text { residents and Spanish citizens took effect on } \\
16 \text { March } 2020\end{array}$ & $\begin{array}{l}\text { Egypt: } \\
\text { All flights in and out of the country were } \\
\text { stopped, effective } 19 \text { March } 2020\end{array}$ \\
\hline & $\begin{array}{l}\text { Vietnam: } \\
\text { Following the progressive closure of borders } \\
\text { to various high risk countries since January, } \\
\text { borders were completely closed to foreigners, } \\
\text { effective } 22 \text { March } 2020\end{array}$ & $\begin{array}{l}\text { Argentina: } \\
\text { Suspension of flights from certain high risk } \\
\text { countries implemented on } 12 \text { March } 2020 \text {, } \\
\text { followed by a } 15 \text { day ban on entry of } \\
\text { non-resident foreigners, effective } 16 \text { March } \\
2020\end{array}$ & $\begin{array}{l}\text { Singapore: Travel ban from Hubei province was } \\
\text { introduced on } 28 \text { January 2020, which was } \\
\text { later expanded to include the entire mainland } \\
\text { China on } 1 \text { February 2020, Daegu and } \\
\text { Cheongdo, South Korea, on } 26 \text { February } 2020 \\
\text { before expanding to other high risk countries } \\
\text { on } 15 \text { March } 2020\end{array}$ \\
\hline \multirow[t]{2}{*}{ Physical distancing measures } & $\begin{array}{l}\text { Mozambique: } \\
\text { No lockdown measures were formally } \\
\text { implemented during the first few months of the } \\
\text { pandemic, but bans on gatherings and other } \\
\text { public activities were introduced on } 1 \text { April } \\
2020\end{array}$ & $\begin{array}{l}\text { Peru: } \\
\text { Compulsory social isolation measures } \\
\text { introduced on } 16 \text { March } 2020 \text { to limit the } \\
\text { spread of the disease for } 15 \text { days, which was } \\
\text { later expanded to last until } 12 \text { April } 2020\end{array}$ & $\begin{array}{l}\text { India: } \\
\text { Total lockdown for the entire country effective } \\
\text { on } 25 \text { March 2020, following a voluntary } \\
\text { shutdown two days before that }\end{array}$ \\
\hline & $\begin{array}{l}\text { China: } \\
\text { Lockdown in Wuhan, following which the CDC } \\
\text { released guidelines for the public to prevent } \\
\text { transmission of covid-19, including not leaving } \\
\text { the house, cancelling social visits, and avoiding } \\
\text { enclosed public spaces and large gatherings }\end{array}$ & $\begin{array}{l}\text { United States: } \\
\text { No centralised enforcement of stay at home } \\
\text { orders, but by late April 2020, most states or } \\
\text { territories had introduced stay at home orders } \\
\text { or advisories }\end{array}$ & $\begin{array}{l}\text { Nigeria: } \\
\text { Lockdowns for some areas of the country, } \\
\text { including Lagos, were introduced on } 26 \text { March } \\
\text { 2020. Nationwide curfew from } 8 \text { pm to } 6 \text { am } \\
\text { was implemented on } 2 \text { May } 2020\end{array}$ \\
\hline \multirow[t]{2}{*}{ Workplace measures } & $\begin{array}{l}\text { Mozambique: } \\
\text { Preventive measures must be in place in all } \\
\text { workplaces, including reduced staffing in face } \\
\text { to face environments, sanitising, frequent } \\
\text { handwashing, and maintaining an interpersonal } \\
\text { distance of } 1.5 \mathrm{~m}\end{array}$ & $\begin{array}{l}\text { Argentina: } \\
\text { The government designated covid-19 as an } \\
\text { occupational hazard, allowing for essential } \\
\text { workers to be compensated if they were } \\
\text { infected }\end{array}$ & $\begin{array}{l}\text { Russia: } \\
\text { Remote workplace measures mandating that } \\
\text { at least } 30 \% \text { of employees, people over } 65 \text {, or } \\
\text { those with chronic conditions work remotely }\end{array}$ \\
\hline & $\begin{array}{l}\text { Niger: } \\
\text { Various measures implemented in the public } \\
\text { administration sector, including cancellation of } \\
\text { internships, suspension of use of lifts, and } \\
\text { restriction on working hours from } 8 \text { am to } 2 \\
\text { pm, between March and May } 2020\end{array}$ & $\begin{array}{l}\text { Peru: } \\
\text { Closure of all but essential workplaces (which } \\
\text { include pharmacies, grocery stores, and } \\
\text { banking institutes) between } 26 \text { March } 2020 \\
\text { and } 12 \text { April } 2020\end{array}$ & $\begin{array}{l}\text { Sweden: } \\
\text { The government encouraged people to work } \\
\text { from home as much as possible, while } \\
\text { workplaces were advised to consider } \\
\text { minimising activities that might present a risk } \\
\text { for transmission of covid-19 }\end{array}$ \\
\hline \multirow[t]{2}{*}{ Social support } & $\begin{array}{l}\text { Uganda: } \\
\text { Food relief distributed to some } 1.5 \text { million } \\
\text { people considered urban poor who were } \\
\text { affected by the lockdown, receiving rations of } \\
\text { several kilos of maize flour, sugar, powdered } \\
\text { milk, beans, and salt }\end{array}$ & $\begin{array}{l}\text { Argentina: } \\
\text { The government introduced price limits for } \\
\text { certain products, such as hand sanitiser, staple } \\
\text { foods, and other products, for } 30 \text { days, } \\
\text { effective } 20 \text { March } 2020\end{array}$ & $\begin{array}{l}\text { Uruguay: } \\
\text { Food support assistance, such as food baskets } \\
\text { were introduced to help deal with food } \\
\text { insecurity }\end{array}$ \\
\hline & $\begin{array}{l}\text { Sri Lanka: } \\
\text { Price caps were set for essential food items, } \\
\text { such as rice, to support food security. A task } \\
\text { force to monitor the delivery of services to rural } \\
\text { areas was also set up }\end{array}$ & $\begin{array}{l}\text { United States: } \\
\text { Support from the federal government for rural } \\
\text { and indigenous communities and subnational } \\
\text { players by providing grants and implementing } \\
\text { programmes targeted at vulnerable } \\
\text { populations, such as communities of colour and } \\
\text { migrants }\end{array}$ & $\begin{array}{l}\text { Fiji: } \\
\text { Government encouragement for households } \\
\text { and farmers to take part in agricultural activities } \\
\text { with the establishment of the home gardening } \\
\text { programme to help support food needs }\end{array}$ \\
\hline \multirow[t]{2}{*}{ Economic support } & $\begin{array}{l}\text { China: } \\
\text { Flexibility on debt repayment and waivers for } \\
\text { late penalties on various debt repayment types, } \\
\text { as well as interest subsidies for new loans }\end{array}$ & $\begin{array}{l}\text { United States: } \\
\$ 1200 \text { stimulus cheque provided to people } \\
\text { with an income under } \$ 99000 \text {, as well as } \\
\text { various measures like a paycheck protection } \\
\text { programme, small business loans, and other } \\
\text { financial relief, such as mortgage deferrals }\end{array}$ & $\begin{array}{l}\text { New Zealand: } \\
\text { Wage subsidy programmes for various sectors } \\
\text { as well as small business loans and debt } \\
\text { repayment deferrals }\end{array}$ \\
\hline & $\begin{array}{l}\text { Thailand: } \\
\text { Relief measures provided to migrants, farmers, } \\
\text { workers, and entrepreneurs. Stimulus package } \\
\text { introduced to mitigate negative economic } \\
\text { effects of the crisis }\end{array}$ & $\begin{array}{l}\text { Spain: } \\
\text { Suspension of mortgage payments for } \\
\text { struggling individuals, as well as a series of } \\
\text { funding measures and a minimum income } \\
\text { scheme }\end{array}$ & $\begin{array}{l}\text { Germany: } \\
\text { Deferral of tax payments, income supports, anc } \\
\text { small business loans }\end{array}$ \\
\hline
\end{tabular}


Table 1 | Examples of national response interventions in countries with low, high, and middle level covid-19 death rates (Continued)

\begin{tabular}{|c|c|c|c|}
\hline Domain & $\begin{array}{l}\text { Lowest death rates (country population >20 } \\
\text { million) }\end{array}$ & $\begin{array}{l}\text { Highest death rates (country population } \\
\qquad>20 \text { million) }\end{array}$ & Middle level death rates \\
\hline \multirow[t]{2}{*}{$\begin{array}{l}\text { Pharmaceutical } \\
\text { interventions }\end{array}$} & $\begin{array}{l}\text { China: } \\
\text { By late } 2020 \text {, four vaccines had entered phase } \\
\text { III trials; vaccines included Sinopharm-BBIP, } \\
\text { Coronavac, and Covidecia }\end{array}$ & $\begin{array}{l}\text { Spain: } \\
\text { Agency for Medicines and Medical Products } \\
\text { (AEMPS) authorised } 32 \text { clinical trials on } \\
\text { covid-19 treatments, registering more than } 26 \\
000 \text { patients }\end{array}$ & $\begin{array}{l}\text { Germany: } \\
\text { In October 2020, the federal government } \\
\text { released a two phase vaccine rollout strategy } \\
\text { prioritising vulnerable populations and health } \\
\text { workers }\end{array}$ \\
\hline & $\begin{array}{l}\text { Thailand: } \\
\text { Several vaccines in development, including a } \\
\text { plant based technology vaccine preparing for } \\
\text { phase I trials in humans in late } 2020\end{array}$ & $\begin{array}{l}\text { United States: } \\
\text { Government agreements with AstraZeneca, } \\
\text { Moderna, and Johnson and Johnson, } \\
\text { respectively, include investments in } \\
\text { manufacturing capabilities }\end{array}$ & $\begin{array}{l}\text { Russia: } \\
\text { By late 2020, the Gam-COVID-Vac (Sputnik V) } \\
\text { vaccine was in phase III trials }\end{array}$ \\
\hline
\end{tabular}

$\mathrm{CDC}=$ Centers for Disease Control and Prevention.

\section{Inner context}

The inner context is driven primarily by the way in which the SARS-CoV-2 virus spreads in populations. ${ }^{2425}$ Evolving evidence of transmission routes and infectivity influenced governments' decisions on how to break chains of transmission and protect health and wellbeing in communities. ${ }^{25-27}$ In turn, the virus is sensitive to anthropogenic pressures and public health interventions (or lack thereof). ${ }^{28} 29$ With widespread community transmission, questions have been raised about variants of SARS-CoV-2 and their increased transmissibility, severity of infection, and the immune response..$^{30-32}$ These uncertainties have played out in the media, shaping public perceptions and disseminating information (and misinformation). Public discourse is further influenced by social media, which has spurred an "infodemic," while undermining public trust and adherence to public health measures. Some countries, including Germany and Sri Lanka, developed campaigns to deal directly with the infodemic (see supplementary table 2; bmj.com). ${ }^{33}$ Experiences in many countries during 2020 emphasised that covid-19 disproportionally affects those in marginalised or oppressed groups. Strict public health measures are necessary to minimise transmission in communities, but they also exert negative social and economic pressures and amplify longstanding inequities. These pressures are disproportionately experienced by equity seeking groups, such as women, children, and LGBTQ+groups, people with disabilities, older adults, and minority and indigenous communities. 34 -39

\section{Outer context}

Factors in the outer context represent structural and institutional components shaping the preparedness and responses of countries. Healthcare is a complex ecosystem that intersects with human rights, equality, security, the environment, migration, economies and markets, among other factors. National responses are shaped by socioeconomic contexts, pre-existing circumstances, infrastructures, politics, legal frameworks, and historical dependencies-locally and globally (see supplementary table 3; bmj.com).

Demographics, for example, have a role in the way in which the pandemic and the responses to it unfold. The younger demographic of African countries is thought to be an advantage in mitigating covid-19. ${ }^{40}$ Cluster identification in these countries might be challenged, however, by younger people showing fewer symptoms and thus hindering successful mitigation strategies. Other countries have used physical features to their advantage. Indeed, geography and health are intrinsically linked and intersect more broadly with direct influences on access to health promoting resources, such as shelter, food, water, and unpolluted ecosystems..$^{41}$ Pre-pandemic health sector investments, reforms, and capacities determined the resilience of the health system to manage the pandemic. ${ }^{2}$

Understanding covid-19 as one of many insecurities ${ }^{42}$ highlights the importance of governance decisions globally, nationally, and locally, and the effects of these on the lives of individuals. This understanding suggests that inner elements are the determining factor for outcomes, but analysis should still consider how authorities mitigated or used structural elements to deal with covid-19.

\section{Applying the framework: drivers, complexities, and uncertainties}

Bringing together the elements identified here, our analysis highlights three areas-the drivers, the complexities, and the uncertainties-that are critical to strengthening national pandemic preparedness response now and in future.

First, countries must consider pre-existing and pandemic sensitive drivers that shape responses. Our analysis emphasises that covid-19 has not been the cause of many of the crises of 2020. Rather, it has amplified underlying and systemic inequalities, vulnerabilities, and fragilities on which health and wellbeing are built on and around. The holistic view we offer is an important picture by which to look back on 2020, as we have done in this analysis, and by which to look ahead in light of vaccines, variants, and the changing political landscape of 2021 and beyond.

Second, countries must view and evaluate responses through a lens that acknowledges pre-existing and pandemic driven complexities. This lens must see that health and wellbeing are equally intertwined with social, economic, political, and ecological circumstances. Our findings also highlight the complexity inherent in responding to pandemics while upholding human rights and protecting lives and livelihoods.

Third, countries must navigate uncertainties in responding to an emerging outbreak of infectious disease, including evolving scientific evidence, emerging variants, and unclear outcomes of new public health or biomedical interventions. These uncertainties have challenged messages on risk, approaches to evaluation, and emphasised the importance of multidisciplinary scientific involvement at the highest levels of national response. Such a response has become increasingly important during the second year of the pandemic as national capacities to sustain responses have been threatened by, and contributed to, uncertainties. 


\section{Conclusion}

Combining these elements in analysis and approach provides an important blueprint for reviewing and evaluating responses to a national pandemic for both covid-19 and future emerging outbreaks of infectious disease. Our roadmap illustrates that health and wellbeing are products of politics, policies, strong and empathetic leadership, coordination, and mechanisms of accountability at all levels and across sectors. Our findings emphasise that there is no perfect single path, and at this point we cannot claim correlation. All interventions are co-dependent, interlinked, and must be viewed in light of the complex systems from which they emerge and with which they interact. Thus to ensure pandemic preparedness and response, countries must now take immediate action to move beyond piecemeal and inequitable approaches. Nations must recognise that the effects of the pandemic reflect our collective neglect of the social, political, economic, ecological, and cultural determinants of health and wellbeing. We must learn lessons today, and this work provides a map to chart a course that incorporates complexity, founded on policies, systems, and actions that create healthy, equitable, and resilient societies to ensure that this is the last pandemic.

\section{Key messages}

- Analysis of responses to covid-19 ought to consider the complexities in which health systems, pandemic preparedness and responses are embedded, locally, nationally, and globally

- Covid-19 has not been the cause of all the crises of 2020 but has amplified underlying and systemic inequalities, vulnerabilities, and fragilities

- A toolset is described with which to analyse the complexity of health systems and pandemic preparedness, evaluate responses, and chart a map moving forward as the world learns to live with covid-19 endemically

- The framework highlights the interplay between governance, strategies, and interventions that are the pillars of responses to a pandemic

- Acknowledgment of complexity is essential to build sustainable and long term approaches to pandemic preparedness and responses

Contributor and sources: This analysis is part of the work commissioned by the Independent Panel for Pandemic Preparedness and Response, which reviewed the national responses of 28 countries. The analysis is separate from the independent panel's final report and has been facilitated by the independent panel secretariat, which is impartial. Data used for the analysis were collected through literature review of peer reviewed papers, policy documents, public reports, and articles that examined national and subnational policy responses; semistructured interviews with country experts and national government written submission of selected countries about their own account of the measures implemented to contain covid-19; and validation of country specific data by experts through written consultation. The views expressed here are solely the authors' and do not represent the views of the independent panel. AS-J, VH, and HL-Q conceived and designed the article. A-SJ, VH, RN, SW, MJ, MV, MT, CDF, SMA, PS, $\mathrm{QC}$, and $\mathrm{HL}-\mathrm{Q}$ collected the data. A-SJ, VH, RN, SW, and HL-Q analysed the data and drafted the manuscript with input from all authors. All authors contributed to revision of the manuscript and round table discussion. ASJ and VH contributed equally and are joint first authors. $\mathrm{HL}-\mathrm{Q}$ is the corresponding author.

Competing interests: We have read and understood BM/ policy on declaration of interests and have no interests to declare.

Provenance and peer review: Commissioned; externally peer reviewed.

This collection of articles was proposed by the Independent Panel for Pandemic Preparedness and Response. Open access fees were funded by the World Health Organisation and Singapore's National Medical Research Council (NMRC/CG/CO26/2017_NUHS). The BM/ commissioned, peer reviewed, edited, and made the decision to publish these articles. Kamran Abbasi was the lead editor for The $B M$.
World Health Organization. Statement on the second meeting of the International Health Regulations (2005) Emergency Committee regarding the outbreak of novel coronavirus (2019-nCoV) 2020. https://www.who.int/news/item/30-01-2020-statement-on-the-secondmeeting-of-the-international-health-regulations-(2005)-emergency-committee-regarding-theoutbreak-of-novel-coronavirus-(2019-ncov)

2 Haldane V, De Foo C, Abdalla SM, etal. Health systems resilience in managing the COVID-19 pandemic: lessons from 28 countries. Nat Med 2021;27:964-80. doi: 10.1038/s41591-021-01381-y pmid: 34002090

3 Damschroder LJ, Aron DC, Keith RE, Kirsh SR, Alexander JA, Lowery JC. Fostering implementation of health services research findings into practice: a consolidated framework for advancing implementation science. Implement Sci2009;4:50. doi: 10.1186/1748-5908-4-50 pmid: 19664226

4 Donabedian A. The quality of care. How can it be assessed?JAMA 1988;260:1743-8. doi: 10.1001/jama.1988.03410120089033 pmid: 3045356

Moore GF, Evans RE, Hawkins J, etal. From complex social interventions to interventions in complex social systems: future directions and unresolved questions for intervention development and evaluation. Evaluation (Lond) 2019:25:23-45.

doi: 10.1177/1356389018803219 pmid: 30705608

6 Kim DH. Introduction to systems thinking. Pegasus Communications Inc, 1999. https://thesystemsthinker.com/wp-content/uploads/2016/03/Introduction-to-Systems-Thinking-IMS013Epk.pdf Maani K, Cavana RY. Systems thinking, system dynamics: managing change and complexity. Prentice Hall, 2007.

8 Massinga Loembé M, Tshangela A, Salyer SJ, Varma JK, Ouma AEO, Nkengasong JN. COVID-19 in Africa: the spread and response. Nat Med 2020;26:999-1003. doi: 10.1038/s41591-020-0961-x pmid: 32528154

9 Mormina M, Nsofor I. What developing countries can teach rich countries about how to respond to a pandemic. The Conversation. 2020;2020:15.

10 World Health Organization. WHO community engagement framework for quality, people-centred and resilient health services. Geneva: World Health Organization, 2017. Contract No. WHO/HIS/SDS/2017.15.

11 Gilmore B, Ndejjo R, Tchetchia A, etal. Community engagement for COVID-19 prevention and control: a rapid evidence synthesis. BMJ Glob Health 2020;5:e003188. doi: 10.1136/bmigh-2020-003188 pmid: 33051285

12 World Health Organization. Community health workers: what do we know about them? 2007. https://www.who.int/hrh/documents/community_health_workers.pdf

13 Morgan M, Fischhoff B, Bostrom A, Atman C. Risk communication: a mental models approach. Cambridge University Press, 2002.

14 Baker MG, Wilson N, Blakely T. Elimination could be the optimal response strategy for covid-19 and other emerging pandemic diseases. BMJ2020;371:m4907.

15 James A, Hendy SC, Plank MJ, Steyn N. Suppression and mitigation strategies for control of COVID-19 in New Zealand.medRxiv. 2020 . https://www.medrxiv.org/content/10.1101/2020.03.26.20044677v1.full.pdfdoi: 10.1101/2020.03.26.20044677

16 van Zandvoort K, Jarvis CI, Pearson CAB, etal. Response strategies for COVID-19 epidemics in African settings: a mathematical modelling study. BMC Med 2020;18:324. doi: 10.1186/s12916-020-01789-2 pmid: 33050951

17 Walker PGT, Whittaker C, Watson OJ, etal. The impact of COVID-19 and strategies for mitigation and suppression in low- and middle-income countries. Science 2020;369:413-22. doi: 10.1126/science.abc0035 pmid: 32532802

18 Ferguson NM, Laydon D, Nedjati-Gilani G, et al. Impact of non-pharmaceutical interventions (NPIs) to reduce COVID-19 mortality and healthcare demand. 2020. https://www.imperial.ac.uk/mrcglobal-infectious-disease-analysis/covid-19/report-9-impact-of-npis-on-covid-19/

19 Firestone MJ, Wienkes H, Garfin J, etal. COVID-19 outbreak associated with a 10-day motorcycle rally in a neighboring state - Minnesota, August-September 2020. MMWR Morb Mortal Wkly Rep 2020;69:1771-6. doi: 10.15585/mmwr.mm6947e1 pmid: 33237891

20 Kayı İ, Sakarya S. Policy analysis of suppression and mitigation strategies in the management of an outbreak through the example of COVID-19 pandemic. Infect Dis Clin Microbiol. 2020;2:30-41doi: 10.36519/idcm.2020.0009.

21 Hartley DM, Perencevich EN. Public health interventions for COVID-19: emerging evidence and implications for an evolving public health crisis. JAMA 2020;323:1908-9. doi: 10.1001/jama.2020.5910 pmid: 32275299

22 von Tigerstrom B, Wilson K. COVID-19 travel restrictions and the International Health Regulations (2005). BMJ Glob Health2020;5:e002629. doi: 10.1136/bmjgh-2020-002629 pmid: 32424016

23 Haldane V, Jung AS, Foo C, etal. Strengthening the basics: public health responses to prevent the next pandemic. BMJ [forthcoming].

24 Li Q, Guan X, Wu P, etal. Early transmission dynamics in Wuhan, China, of novel coronavirus-infected pneumonia. N Engl J Med 2020;382:1199-207. doi: 10.1056/NEJMoa2001316 pmid: 31995857

25 Coronaviridae Study Group of the International Committee on Taxonomy of Viruses. The species severe acute respiratory syndrome-related coronavirus: classifying 2019-nCoV and naming it SARS-CoV-2. Nat Microbiol 2020;5:536-44. doi: 10.1038/s41564-020-0695-z pmid: 32123347

26 van Doremalen N, Bushmaker T, Morris DH, etal. Aerosol and surface stability of SARS-CoV-2 as compared with SARS-CoV-1. N Engl J Med 2020;382:1564-7. doi: 10.1056/NEJMc2004973 pmid: 32182409

27 Morawska L, Milton DK. It is time to address airborne transmission of coronavirus disease 2019 (COVID-19). Clin Infect Dis 2020;71:2311-3. doi: 10.1093/cid/ciaa939 pmid: 32628269 
28 Petersen E, Koopmans M, Go U, etal. Comparing SARS-CoV-2 with SARS-CoV and influenza pandemics. Lancet Infect Dis 2020;20:e238-44. doi: 10.1016/S1473-3099(20)30484-9 pmid: 32628905

29 Maragakis L. Coronavirus second wave? Why cases increase: Johns Hopkins Medicine; 2020 https://www.hopkinsmedicine.org/health/conditions-and-diseases/coronavirus/first-and-secondwaves-of-coronavirus.

30 Xie X, Liu Y, Liu J, etal. Neutralization of SARS-CoV-2 spike 69/70 deletion, E484K and N501Y variants by BNT162b2 vaccine-elicited sera. Nat Med 2021;27:620-1. doi: 10.1038/s41591-021-01270-4 pmid: 33558724

31 Sabino EC, Buss LF, Carvalho MPS, etal. Resurgence of COVID-19 in Manaus, Brazil, despite high seroprevalence. Lancet2021;397:452-5. doi: 10.1016/S0140-6736(21)00183-5 pmid: 33515491

32 Galloway SE, Paul P, MacCannell DR, etal. Emergence of SARS-CoV-2 B.1.1.7 Lineage - United States, December 29, 2020-January 12, 2021. MMWR Morb Mortal Wkly Rep 2021;70:95-9. doi: 10.15585/mmwr.mm7003e2 pmid: 33476315

33 The Lancet Infectious Diseases. The COVID-19 infodemic. Lancet Infect Dis 2020;20:875. https://www.ncbi.nlm.nih.gov/pmc/articles/PMC7367666/. doi: 10.1016/S1473-3099(20)30565-X pmid: 32687807

34 Shadmi E, Chen Y, Dourado I, etal. Health equity and COVID-19: global perspectives. Int J Equity Health 2020;19:104. doi: 10.1186/s12939-020-01218-z pmid: 32586388

35 Smith J. Overcoming the 'tyranny of the urgent': integrating gender into disease outbreak preparedness and response. Gender \& Development 2019;27:355-69doi: 10.1080/13552074.2019.1615288

36 Jiao WY, Wang LN, Liu J, et al. Behavioral and emotional disorders in children during the COVID-19 epidemic. J Pediatr 2020;221:264-6 e1.

37 World Health Organization. Older people and COVID-19.2020 https://www.who.int/teams/socialdeterminants-of-health/demographic-change-and-healthy-ageing/covid-19.

38 Lebrasseur A, Fortin-Bédard N, Lettre J, etal. Impact of COVID-19 on people with physical disabilities: A rapid review. Disabil Health /2021;14:101014 doi: 10.1016/j.dhjo.2020.101014 pmid: 33158795

39 Curtice K, Choo E. Indigenous populations: left behind in the COVID-19 response. Lancet 2020;395:1753. doi: 10.1016/50140-6736(20)31242-3 pmid: 32505246

40 Diop BZ, Ngom M, Pougué Biyong C, Pougué Biyong JN. The relatively young and rural population may limit the spread and severity of COVID-19 in Africa: a modelling study. BMJ Glob Health 2020;5:e002699. doi: 10.1136/bmjgh-2020-002699 pmid: 32451367

41 Dummer TJ. Health geography: supporting public health policy and planning. CMAJ 2008;178:1177-80. doi: 10.1503/cmaj.071783 pmid: 18427094

42 Leach M, MacGregor H, Scoones I, Wilkinson A. Post-pandemic transformations: How and why COVID-19 requires us to rethink development. World Dev 2021;138:105233. doi: 10.1016/j.worlddev.2020.105233 pmid: 33100478

This is an Open Access article distributed under the terms of the Creative Commons Attribution IGO License (https://creativecommons.org/licenses/by-nc/3.0/igo/), which permits use, distribution, and reproduction for non-commercial purposes in any medium, provided the original work is properly cited. 